\title{
Biruh Tesfa ('bright future'): A program for poor, urban girls at risk of exploitation and abuse in Addis Ababa, Ethiopia
}

Population Council

Follow this and additional works at: https://knowledgecommons.popcouncil.org/departments_sbsr-pgy

Part of the Demography, Population, and Ecology Commons, Family, Life Course, and Society Commons, Gender and Sexuality Commons, Inequality and Stratification Commons, and the International Public Health Commons How does access to this work benefit you? Let us know!

\section{Recommended Citation}

"Biruh Tesfa ('bright future'): A program for poor, urban girls at risk of exploitation and abuse in Addis Ababa, Ethiopia," program brief. Addis Ababa: Population Council, 2006. 


\section{PROGRAM BRIEF}

\section{Biruh Tesfa}

('BRIGHT FUTURE')

\section{A program for poor, urban girls at risk of exploitation and abuse in Addis Ababa, Ethiopia}

Low income and slum areas in urban sub-Saharan Africa attract large numbers of rural-urban migrants in search of work and educational opportunities. Many of these migrants are adolescents from poor rural areas, who risk the dangers and hazards of life in the slums, in the hopes of carving out a better life for themselves. Population Council and Ministry of Youth and Sport research in low income and slum areas of Addis Ababa indicated that female adolescent migrants outnumbered male migrants, with these settings home to large concentrations of vulnerable girls. Not only did girls migrate in search of education and jobs, but they often came to escape forced early marriages in their rural homes. These girls arrive knowing little about life in dense urban centers, often with little or no education, and no family members or friends to turn to. Many new arrivals are initially absorbed into domestic work; some eventually drift into sex work either for lack of choice or in pursuit of better pay and fewer working hours. Such girls are at ongoing risk of coerced or forced sex, exchange of sex for gifts, money, support or survival, and exploitative labor.

Though most of the youth programs in Ethiopia such as peer education and youth centers are located in urban areas, and indeed many are in slum areas like Mercato, such girls are rarely beneficiaries of these efforts. Biruh Tesfa is a joint project by the Ethiopian Ministry of Youth and Sport and the Addis Ababa Youth and Sport Commission, with technical assistance from the Population Council and support from UNFPA, DFID, and Turner Foundation. Implemented in the Mercato area of Addis Ababa, the project targets out-of-school girls aged 10 to 19 , most of whom are migrants, living away from parents and family members, and unlikely to be reached by current programs.

\section{Safe spaces, social networks and support for marginalized girls}

Birhu Tesfa (meaning "Bright Future" in Amharic) is a program for adolescent girls in the Mercato area of Addis Ababa. The program is designed to assist out-of-school girls by creating safe spaces through which they can build support networks with other
I get up at 6 in the morning and start work by cleaning the house. I fetch water and wash the dirty jibbas. I leave them soaking and go to the shop if there is something to be bought, then I make the beds - there are five or six beds that we rent ... Then I go back and wash the dishes and I get the dishes that people used for lunch and I wash them too. By this time it is dark ...

... I don't have any friends around here. If she [employer] finds me talking to someone, she says, "Why are you talking and not doing work?" So I don't talk to anyone.

-Addis Ababa domestic worker, age 14 , migrated at age 14 from Amhara Region, 5 years education 
Biruh Tesfa participant talks about her past and her aspirations ...

"I lived with my family, both mother and father. My

parents wanted to marry me, but I refused and came to Addis Ababa. First I told them that I wanted to go to school. But they were not

willing ... I said to myself that I will get a job [in Addis Ababa] as a domestic worker and pursue my education ...

... I'd love to be a doctor ... I want to quit this

kind of work because we face ridicule everyday. I also want to tell my story - that I ran away from my family in the countryside and I came to Addis Ababa and completed school in Addis.

"-Addis Ababa domestic worker, age 17 , migrated at age

16 from Amhara Region, no education" girls, as well as relationships with supportive adults. The program promotes functional literacy, life skills, livelihoods skills, and reproductive health education through girls' clubs led by adult female mentors. Girls clubs are held in meeting spaces donated by the kebele (local administration). These meeting spaces are simple social halls in the community, equipped with benches and blackboards. Meeting spaces remain a challenge. In slum areas, space is at a premium and several clubs are forced to meet in one room, with some meeting facilities lacking running water or proper toilets. Groups meet for two hours, three times a week. Girls whose time is limited due to work or control by employers may attend less regularly. Meeting times are varied to accommodate the various schedules of working girls. Some groups meet in the morning hours, some in the afternoon, and some in the early evening, a session which is dominated by domestic workers.

\section{Reaching invisible and hard-to-reach girls}

Forming Birhu Tesfa groups is a challenge, given that the most vulnerable girls are often out of sight and inaccessible, engaged in domestic work or other types of survival work. Frequently, employers do not approve of girls being away from work or engaged in social activities. Birhu Tesfa mentors are adult women recruited from Mercato area, most of whom are local women's leaders, and active and well-known in the community. These 18 mentors are assigned specified areas of operation within Mercato, most often in their own areas of residence. In the beginning of the program, mentors go house to house, to introduce themselves and the program. Through these home visits, they identify out-of-school girls who may be eligible, including domestic workers. They describe the program to employers or guardians and negotiate the girls' participation. Mentors often emphasize the non-formal education component of the program, finding that employers and guardians are generally supportive of educational opportunities for girls.

\section{Engaging large numbers of girls in the program}

The project has already received an enthusiastic response from the community-over 600 girls joined Biruh Tesfa, amounting to roughly 60 percent of eligible out-of-school girls. One hundred and thirty domestic workers are participating in the program, or about 20 percent of program participants. About one third of participants are younger adolescents aged 10 to 14 and over one half of participating girls have never attended school before.

\section{Resources}

Erulkar AS, Mekbib T, Simie N, Gulema T. 2004. "Adolescent life in low-income and slum areas of Addis Ababa Ethiopia"Accra: Population Council.

2006. "Differential use of adolescent reproductive health programs in Addis Ababa, Ethiopia," Journal of Adolescent Health, Vol 38(3), 253-60.

2006. "Migration and Vulnerability Among Adolescents in Slum Areas of Addis Ababa, Ethiopia," Journal of Youth Studies, Vol. 9, No. 3, 261-274

2004. "The experience of adolescence in rural Amhara region Ethiopia" Accra: Population Council.

Child Marriage Briefing Sheet: Ethiopia, Population Council, NY, www.popcouncil.org

For more information on Berhane Hewan program, contact:

W/o Tsahai Gulema

Ministry of Youth \& Sports

P.O. Box 3241

Addis Ababa, Ethiopia
Addis Ababa Youth \& Sport Commission P.O. Box 32131

Addis Ababa, Ethiopia
Helen Amdemikael

UNFPA Ethiopia

P.O. Box 5580

Addis Ababa, Ethiopia

amdemikael@unfpa.org
Dr. Annabel Erulkar Population Council

P.O. Box CT 4906

Accra, Ghana

aerulkar@pcaccra.org
Dr. Tekle Ab Mekbib Population Council

P.O. Box 33998

Addis Ababa, Ethiopia mekbibt@ethionet.et 